\title{
KANDUNGAN NITRAT DAUN, PERTUMBUHAN, DAN HASIL BIOMASSA SAWI DAN PAKCOY PADA PEMBERIAN PUPUK NITROGEN ANORGANIK DAN KOMPOS AZOLLA SECARA BERIMBANG
}

\author{
Pratiwi Pratiwi $^{1}$, Marwanto Marwanto ${ }^{1 *}$,Widodo Widodo ${ }^{1}$, Merakati Handajaningsih ${ }^{1}$ \\ ${ }^{1}$ Program Studi Agroekoteknologi Fakultas Pertanian Universitas Bengkulu \\ *Corresponding Author: marwanto@unib.ac.id
}

\begin{abstract}
[LEAF NITRATE CONTENT, GROWTH, AND BIOMASS YIELD OF GREEN MUSTARD AND CHINESE CABBAGE FOLLOWING BALANCED APPLICATION OF INORGANIC NITROGEN FERTILIZER AND AZOLLA COMPOST]. The aim of this study was to determine the application rate of Azolla compost, either alone or combined with inorganic $\mathrm{N}$ fertilizers, to produce high biomass of green mustard and Chinese cabbage with low leaf nitrate content. The pot experiments were carried out at the Research Plot of the Faculty of Agriculture located in Bengkulu University Campus from December 2019 to January 2020 with five treatments arranged in a completely randomized design with five replications. The treatments were $100 \% \mathrm{IF}_{\text {or }} \mathrm{IF}_{100}(42.0 \mathrm{mg} \mathrm{N} / \mathrm{kg}$ soil $), 100 \% \mathrm{AC}$ or $\mathrm{AC}_{100}\left(4000 \mathrm{mg} / \mathrm{kg}\right.$ soil), $\mathrm{IF}_{75}(31.0 \mathrm{mg} \mathrm{N} / \mathrm{kg}$ soil $)+\mathrm{AC}_{25}(1000 \mathrm{mg} / \mathrm{kg}$ soil $), \mathrm{IF}_{50}(21.0 \mathrm{mg} / \mathrm{kg} \mathrm{soil})+\mathrm{AC}_{50}(2000 \mathrm{mg} /$ $\mathrm{kg}$ soil), and $\mathrm{IF}_{25}(10.5 \mathrm{mg} / \mathrm{kg}$ soil $)+\mathrm{AC}_{75}(3000 \mathrm{mg} / \mathrm{kg}$ soil). The results showed that partial replacement of IF with $\mathrm{AC}\left(\mathrm{IF}_{75}+\mathrm{AC}_{25}\right)$ produced plant growth and biomass yield similar to $\mathrm{IF}_{100}$ or higher than $\mathrm{IF}_{100}$ and $\mathrm{AC}_{100}$. The treatment produced plant biomass of $9.35 \mathrm{~g} /$ plant for green mustard and $167.10 \mathrm{~g} / \mathrm{plant}$ for pakcoy, $32 \%$ and $35 \%$ higher than $\mathrm{AC}_{100}$ treatment respectively. The leaf nitrate content was $1080-2760 \mathrm{mg} / \mathrm{kg}$ for green mustard and 2310 - $2820 \mathrm{mg} / \mathrm{kg}$ for Chinese cabbage, lower than the maximum limit of safe nitrate for consumption which was set at $3100 \mathrm{mg} / \mathrm{kg}$. Overall, compared with their sole applications, the partial substitution of inorganic $\mathrm{N}$ fertilizer with Azolla compost represents the most effective practice to promote the biomass yield of low-nitrate green mustard and Chinese cabbage.
\end{abstract}

Keyword: leafy vegetables, integrated nutrient management, organic fertilizer, inorganic fertilizer

\begin{abstract}
ABSTRAK
Tujuan penelitian ini menentukan dosis aplikasi kompos Azolla, baik sendiri atau dipadukan dengan pupuk $\mathrm{N}$ anorganik, untuk meningkatkan hasil biomassa sawi hijau dan pakcoy yang rendah kandungan nitratnya. Percobaan dilakukan di Lahan Percobaan Fakultas Pertanian Universitas Bengkulu pada Desember 2019-Januari 2020. Aplikasi kompos Azolla baik sendiri atau dipadukan dengan pupuk $\mathrm{N}$ anorganik dijadikan sebagai perlakuan dan perlakuan ditata dengan Rancangan Acak Lengkap dengan lima ulangan. Perlakuan terdiri atas pemberian $100 \%$ pupuk N anorganik atau $\mathrm{IF}_{100}\left(42,0 \mathrm{mg} \mathrm{N} / \mathrm{kg}\right.$ tanah), $100 \%$ kompos Azolla atau $\mathrm{AC}_{100}\left(4000 \mathrm{mg} / \mathrm{kg}\right.$ tanah), $\mathrm{IF}_{75}(31,0 \mathrm{mg} \mathrm{N} / \mathrm{kg}$ tanah) $+\mathrm{AC}_{25}(1000 \mathrm{mg} / \mathrm{kg}$ tanah $), \mathrm{IF}_{50}(21,0 \mathrm{mg} / \mathrm{kg}$ tanah $)+\mathrm{AC}_{50}(2000 \mathrm{mg} / \mathrm{kg}$ tanah $)$, dan $\mathrm{IF}_{25}(10,5 \mathrm{mg} / \mathrm{kg}$ tanah $)$ $+\mathrm{AC}_{75}(3000 \mathrm{mg} / \mathrm{kg}$ tanah). Hasil penelitian menunjukkan bahwa perlakuan berpengaruh nyata terhadap tinggi tanaman (untuk sawi hijau dan pakcoy), jumlah daun, luas daun, dan bobot segar akar (hanya untuk sawi hijau) dan hasil biomassa kedua tanaman dengan indikator bobot segar daun, bobot segar tanaman, dan bobot kering tanaman. Perlakuan $\mathrm{IF}_{75}+\mathrm{AC}_{25}$ menghasilkan biomassa berbobot 9,35 g/tanaman untuk sawi hijau dan 167,10 g/tanaman untuk pakcoy atau secara berturut-turut $32 \%$ dan $35 \%$ lebih tinggi daripada perlakuan $\mathrm{AC}_{100}$. Kandungan nitrat daun terukur sebanyak $1080-2760 \mathrm{mg} / \mathrm{kg}$ untuk sawi hijau dan $2310-2820 \mathrm{mg} / \mathrm{kg}$ untuk pakcoy, lebih rendah dari batas maksimal nitrat yang aman dikonsumsi yang ditetapkan sebanyak $3100 \mathrm{mg} / \mathrm{kg}$. Secara keseluruhan, dibandingkan dengan penggunaannya secara tunggal, substitusi sebagian pupuk $\mathrm{N}$ anorganik dengan kompos Azolla merupakan pengelolaan nutrisi yang paling efektif untuk meningkatkan pertumbuhan dan hasil biomassa sawi hijau dan pakcoy yang rendah kandungan nitratnya.
\end{abstract}

Kata kunci: sayuran berdaun, pengelolaan hara terpadu, pupuk organik, pupuk anorganik 


\section{PENDAHULUAN}

Nitrogen $(\mathrm{N})$ merupakan unsur hara yang sangat penting dibutuhkan untuk pertumbuhan tanaman. Meskipun menyumbang kurang dari 5\% dari total $\mathrm{N}$ di dalam tanah (Brady \& Weil, 2008), senyawa N anorganik (mis. $\mathrm{NH}_{4}^{+}, \mathrm{NO}_{2}^{-}$, dan $\mathrm{NO}_{3}^{-}$) merupakan bentuk utama dari unsur yang diserap oleh sebagian besar tumbuhan. Urea $\left[\mathrm{CO}\left(\mathrm{NH}_{2}\right)_{2}\right]$ merupakan pupuk $\mathrm{N}$ anorganik yang paling umum digunakan di dunia, dengan perkiraan peningkatan permintaan global sebesar $1,6 \%$ per tahun hingga 2022 (IFA, 2018).

Setelah pupuk $\mathrm{N}$ anorganik diaplikasikan ke dalam sistem pertanian, senyawanya diserap oleh tanaman atau diubah menjadi berbagai bentuk lain melalui proses oksidasi. Nitrogen yang berlebih akan hilang dalam bentuk ionik atau gas melalui pencucian, penguapan, dan denitrifikasi (Brady \& Weil, 2008). Dalam beberapa kasus, kehilangan $\mathrm{N}$ dalam bentuk amonia $\left(\mathrm{N}-\mathrm{NH}_{3}\right)$ terjadi lebih dari $50 \% \mathrm{~N}$ yang diaplikan (Tasca et al., 2011). Besarnya kehilangan $\mathrm{NH}_{3}$ bervariasi karena bergantung pada teknologi yang digunakan untuk mengaplikasikan pupuk (Stafanato et al., 2013; Silva et al., 2017), sifat tanah (Sunderlage \& Cook, 2018), dan kondisi lingkungan (Otto et al., 2017). Jika nitrat tidak diserap oleh akar tanaman, senyawa ini akan terbawa oleh limpasan atau pencucian ke dalam tanah bersama dengan air (Tamme et al., 2009).

Ketersediaan $\mathrm{N}$ bagi tanaman meningkat ketika pupuk $\mathrm{N}$ anorganik yang berlebih diberikan. Hal ini meningkatkan potensi ancaman terhadap lingkungan sekitarnya secara intensif (Sharifi et al., 2011). Ada hubungan yang erat antara aplikasi pupuk $\mathrm{N}$ yang berlebihan dengan masalah lingkungan seperti eutrofikasi, efek rumah kaca, dan hujan asam (Wang et al., 2002). Studi oleh Donner \& Kucharik (2003) menunjukkan bahwa ketika tingkat aplikasi pupuk $\mathrm{N}$ meningkat $30 \%$, hasil jagung meningkat $4 \%$, tetapi jumlah nitrat yang hilang melalui pencucian meningkat sebesar 53\%. Meskipun hasil menurun 10\% ketika tingkat aplikasi pupuk $\mathrm{N}$ dikurangi sebesar $30 \%$, kehilangan pencucian berkurang $37 \%$.

Aplikasi pupuk $\mathrm{N}$ anorganik yang berlebihan juga meningkatkan akumulasi nitrat di bagian tanaman yang dapat dimakan seperti sayuran berdaun hijau (green leafy vegetables) (Pavlou et al., 2007). Keberadaan nitrat di sayuran, makanan dan air membahayakan kesehatan manusia. Nitrat sendiri secara relatif tidak beracun (Mensinga et al., 2003), tetapi sekitar 5\% dari semua nitrat yang tertelan diubah di air liur dan saluran cerna menjadi nitrit yang bersifat lebih toksik (Pannala et al., 2003).

Pupuk organik menjadi alternatif untuk mengatasi penggunaan pupuk anorganik serta unsur hara terutama nitrogen pada tanaman, pupuk organik lebih ramah lingkungan dibandingkan pupuk anorganik, pupuk organik dapat memperbaiki struktur tanah, meningkatkan kesuburan tanah serta berkelanjutan (Garcia-Ruíz et al., 2012). Salah satu tumbuhan yang kaya $\mathrm{N}$ yang dapat digunakan sebagai kompos adalah Azolla (Jumadi et al., 2014). Menurut Jumadi et al. (2014), pemberian kompos $A$. microphylla dapat mengurangi kebutuhan pupuk $\mathrm{N}$ anorganik. Namun demikian, nutrisi yang terkandung di dalam pupuk organik harus termineralisasi oleh mikroorganisme tanah untuk melepaskan nutrisinya ke dalam tanah. Proses ini berlangsung lambat, tergantung pada karakteristik bahan organiknya (Hirzel \& Salazar, 2011). Proses mineralisasi yang lambat ini mengurangi resiko pencucian nutrisinya, namun gagal dalam memasok nutrisi yang cukup untuk pertumbuhan tanaman (Hirzel \& Salazar, 2011). Menggabungkan pemberian kompos dengan pupuk anorganik merupakan praktik pengelolaan nutrisi tanaman secara terintegrasi (integrated plant nutrient management) yang menarik. Menurut Nair (2019), pengelolaan nutrisi tanaman secara terintegrasi adalah pemeliharaan atau penyesuaian kesuburan tanah dan pasokan hara tanaman ke tingkat yang optimal untuk mempertahankan produksi tanaman yang diinginkan melalui optimalisasi manfaat dari semua kemungkinan sumber hara tanaman.

Strategi ini akan memungkinkan untuk mengurangi tingkat pemberian pupuk anorganik ke dalam tanah sehingga mengurangi risiko degradasi tanah, pencucian unsur hara sekaligus menjaga kesehatan tanah dan lingkungan (Zebarth et al., 2009). serta mengurangi (defortifikasi) kandungan nitrat daun (Wang et al., 2002).

Sawi hijau dan pakcoy merupakan sayuran berdaun hijau salah satu sayuran yang paling banyak dikonsumsi di Indonesia karena memiliki kandungan mineral dan nilai ekonomis yang tinggi. Kedua jenis sayuran ini termasuk konsumtif terhadap pemupukan N (Kumar-Premi \& Thomas, 2015). Natesh et al. (2017) melaporkan bahwa tanaman hortikultura, khususnya sayuran berdaun hijau memegang peranan penting karena mengandung lebih banyak vitamin dan mineral dibandingkan jenis sayuran lainnya. Sayuran berdaun hijau yang dibudidayakan secara konvensional mengandung tingkat nitrat tertinggi (Prasad \& Chetty, 2008), dan Chinese cabbage (termasuk sawi hijau dan pakcoy) diklasifikasikan memiliki kandungan nitrat yang sangat tinggi (antara 1000-2500 mg/kg) (Santamaria, 2006).

Mengingat mengonsumsi nitrat yang tinggi dapat menyebabkan efek patologis yang serius pada manusia (Mensinga et al., 2003), maka budidaya tanaman sayuran berdaun dengan kandungan nitrat rendah sangat penting. Komite Ahli Bersama dari Organisasi Pangan dan Pertanian (JECFA) Perserikatan Bangsa-Bangsa/Organisasi Kesehatan Dunia dan Komite Ilmiah Komisi Eropa (EC) tentang Pangan juga telah menetapkan asupan harian yang dapat diterima untuk nitrat sebanyak dari $0-3,7 \mathrm{mg} / \mathrm{kg}$ bobot badan (Santamaria, 2006). Menurut Badan Perlindungan Lingkungan Amerika Serikat (EPA), dosis referensi 
untuk nitrat setara dengan sekitar $7,0 \mathrm{mg} \mathrm{kg}^{-1}$ berat badan per hari (Mensinga et al., 2003). Setiap negara menerapkan batas maksimal nitrat yang diperbolehkan di sayuran. Sebagai contoh, batas maksimal nitrat di sayuran di China ditetapkan sebanyak $3100 \mathrm{mg} / \mathrm{kg}$ (Zhou et al., 2000).

Defortifikasi nitrat daun merupakan upaya mengurangi konsentrasi nitrat tanaman terutama tanaman sayuran berdaun hijau dengan cara mengurangi pemu pukan $\mathrm{N}$ anorganik dan mensubstitusinya dengan pupuk organik tanpa mengurangi produksi biomassanya. Dengan demikian, jumlah nitrat yang diserap oleh tanaman akan berkurang. Liu et al. (2014) melaporkan bahwa selada yang diperlakukan dengan pemberian pupuk anorganik menunjukkan pertumbuhan yang paling baik, namun juga memiliki konsentrasi nitrat daun yang tertinggi. Penelitian lainnya melaporkan bahwa sayuran berdaun hijau merupakan sumber utama asupan nitrat oleh manusia dan merupakan sekitar 40 - 92\% dari asupan rata-rata harian (Ximenes et al., 2000). Oleh karena itu, defortifikasi kandungan nitrat sayuran berdaun hijau perlu dilakukan dengan menerapkan integrated nutrient management. Tujuan penelitian ini untuk mengevaluasi pemberian kompos Azolla, baik sendiri atau dipadukan dengan pupuk $\mathrm{N}$ anorganik, untuk meningkatkan hasil biomassa sawi hijau dan pakcoy yang rendah kandungan nitratnya.

\section{METODE PENELITIAN}

\section{Lokasi Percobaan dan Bahan Tanam}

Percobaan dilakukan di Lahan Percobaan Fakultas Pertanian Universitas Bengkulu (15m di atas permukaan laut, $2^{0} 16^{\prime} \mathrm{LU}$ dan $3^{0} 31^{\prime} \mathrm{LS}$ dan antara $101^{0} 01^{\prime}-03^{\circ}$ 41'BT) pada bulan Desember 2019-Januari 2020. Saat penelitian, suhu udara rata-rata $26,91{ }^{\circ} \mathrm{C}$ dan $26,84{ }^{0} \mathrm{C}$,rata-rata lama penyinaran matahari sebesar $76,7 \%$ dan $65,6 \%$, rata-rata kelembaban udara sebesar $83,83 \%$ dan $86,16 \%$, dan curah hujan sebesar 76 $\mathrm{mm}$ dan $470 \mathrm{~mm}$ secara berturut-turut pada bulan Desember 2019 dan Januari 2020.

Tanah untuk penelitian tergolong dalam tatanan tanah Ultisol (FAO, 2006). Tanah untuk diisikan ke dalam polybag diambil dari Kebun Percobaan. Tanah diambil dari tiga titik yang berbeda di kedalaman 0 $20 \mathrm{~cm}$, dicampur hingga rata, dikeringanginkan selama dua hari, dihaluskan, dan disaring dengan saringan jaring 2 $\mathrm{mm}$, dan disimpan pada suhu ruang sampai digunakan.

Tanah yang sama diambil dari titik yang berbeda sebagai sampel tanah untuk dianalisis sifat fisik dan kimianya. Pengambilan sampel tanah dilakukan dengan menggunakan ring pengambilan sampel tanah (diameter $10 \mathrm{~cm}$ ) di tiga lokasi di Lahan Percobaan Fakultas Pertanian Universitas Bengkulu pada kedalaman 0 $20 \mathrm{~cm}$ sebelum percobaan dimulai. Sampel tanah ini dikeringkananginkan pada suhu kamar selama 3 hari, dihaluskan secara manual, dan diayak dengan saringan berukuran $2 \mathrm{~mm}$. Sampel tanah yang telah kering dianalisis untuk menentukan sifat fisik dan kimianya di laboratorium Ilmu Tanah Fakultas Pertanian Universitas Bengkulu, yang meliputi pH, C, N, P, K, Al-dd, KTK, dan BV (Tabel 1).

Percobaan ini menggunakan dua tanaman, yaitu benih F1 sawi hijau varietas Tosakan dan benih F1 pakcoy varietas Nauli. Benih yang baik dipilih dan disterilkan dengan cara direndam dalam etanol 10\% selama 3 menit. Kemudian benih dicuci minimal tiga kali dengan akuades, dan disterilkan kembali dengan larutan $\mathrm{NaClO}$ 5\% selama 30 menit. Benih yang telah disterilkan dicuci dalam air suling dan disimpan dalam inkubator $25^{\circ} \mathrm{C}$ selama 48 jam sebelum disemai.

\section{Persiapan Kompos Azolla}

Tanaman Azolla (Azolla microphyla Kaufl) seberat satu kilogram dikumpulkan dari sawah di sekeliling tempat penelitian. Biomassa segar Azolla dicuci dengan air tiga kali hingga bersih, kemudian dikeringkan dalam oven pada suhu $55{ }^{0} \mathrm{C}$ sampai kadar air sekitar $60 \%$. Biomassa Azolla kering dituang ke dalam ember plastik, $250 \mathrm{~mL}$ tetes tebu ditambahkan dan dicampur dan selanjutnya ember plastik ditutup dengan plastik hitam untuk pengomposan. Proses pengomposan dilanjutkan selama 1 minggu. Kompos Azolla yang dipanen dikeringkan dalam oven pada suhu $55{ }^{\circ} \mathrm{C}$, dan kemudian digiling sampai lulus saringan 2,00 $\mathrm{mm}$ sebelum analisis.

\section{Analisis Tanah dan Kompos Azolla}

Sampel tanah yang telah kering dianalisa sifat fisik dan kimianya, yang meliputi $\mathrm{pH}, \mathrm{C}, \mathrm{N}, \mathrm{P}, \mathrm{K}, \mathrm{Al}-$ dd, KTK, dan BV, sedang sampel kompos Azolla dianalisa C, N, P, dan Al-dd (Tabel 1). Tingkat kemasaman $(\mathrm{pH})$ tanah diukur menggunakan $\mathrm{pH}$ meter $(\mathrm{pH}$ Meter HM-10P, DKK-TOA Corp., Tokyo, Japan) pada rasio tanah dan air distilasi 1:1. Sampel tanah dan kompos Azolla secara terpisah dihancurkan menggunakan metode digesti asam salisilat- $\mathrm{H}_{2} \mathrm{SO}_{4}^{-}$hidrogen peroksida untuk dianalisa total $\mathrm{N}$ dengan metode Mikro Kjeldhal dan P dengan metode Bray 1 (Ohyma et al., 1991). Kandungan $\mathrm{K}$ ditentukan dengan menggunakan larutan digesti dan spektrofotometer serapan atom (Z-5300, Hitachi, Tokyo, Jepang). Bahan organik (C) ditentukan dengan metode Walkley \& Black (Díaz - Zorita, 1999). KTK diukur dengan metode ekstraksi ammonium asetat, dan Al-dd dengan metode ekstraksi $\mathrm{KCl}$ (Balai Penelitian Tanah, 2009).

\section{Rancangan Penelitian dan Perlakuan}

Aplikasi pupuk $\mathrm{N}$ anorganik (IF) baik sendiri atau dipadukan dengan kompos Azolla dijadikan sebagai perlakuan dan perlakuan ini ditata dengan Rancangan Acak Lengkap dengan lima ulangan. Perlakuan terdiri atas lima taraf, yaitu (1) pemberian $100 \%$ urea atau $\operatorname{IF}_{100}(0.91 \mathrm{~g} /$ polybag), (2) $75 \%$ urea 
atau $\operatorname{IF}_{75}(0,67 \mathrm{~g} /$ polybag $)+25 \%$ kompos Azolla atau $\mathrm{AC}_{25}(10 \mathrm{~g} /$ polybag $)$, (3) $\mathrm{IF}_{50}(0,46 \mathrm{~g} /$ polybag $)$ $+\mathrm{AC}_{50}(20 \mathrm{~g} /$ polybag $),(4) \mathrm{IF}_{25}(0,22 \mathrm{~g} /$ polybag $)+$ $\mathrm{AC}_{75}$ (30 g/polybag), dan (5) 100\% kompos Azolla atau $\mathrm{AC}_{100}(40 \mathrm{~g} /$ polybag). Perlakuan ditata dengan Rancangan Acak Lengkap dengan lima ulangan dan setiap ulangan terdiri atas lima polibag. $\mathrm{IF}_{100}$ setara dengan $200 \mathrm{~kg} /$ ha sebagai urea atau setara $1,00 \mathrm{~g} /$ polybag, sedang $\mathrm{AC}_{100}$ diberikan sebanyak $8000 \mathrm{~kg} / \mathrm{ha}$ atau setara $43,95 \mathrm{~g} /$ polybag.

\section{Pengelolaan Tanaman}

Benih sawi dan pakcoy yang telah disiapkan sebelumnya disemaikan selama 14 hari di baki polistiren berisi 128 sel dan gambut yang telah dipupuk digunakan sebagai media. Bibit (seedling) kedua tanaman dipindahkan pada tahap dua daun ke dalam polybag berisi 10 $\mathrm{kg}$ tanah yang telah dipersiapkan sebelumnya.

Tanah yang diisikan ke dalam polibag bersifat masam dan berkadar $\mathrm{C}$ rendah. Kemasaman tanah karena $\mathrm{pH}$ yang rendah dinetralkan melalui penambahan dolomit sebanyak 6,51 ton/ha atau setara dengan $29,7 \mathrm{~g} /$ polybag. Kandungan $\mathrm{C}$ yang rendah diatasi dengan penambahan pupuk kandang sapi sebanyak $202 \mathrm{~g} /$ polybag. Bahan pembenah tanah ini dicampur rata dengan tanah dan dibiarkan selama 14 hari. Setelah dibiarkan selama 14 hari, tanah dicampur secara merata dengan pupuk seluruh dosis kompos Azolla (sesuai perlakuan), TSP sebanyak $0,25 \mathrm{~g} /$ polybag dan $\mathrm{KCl}$ sebanyak 0,30 g/polybag (Balai Pengkajian Teknologi Pertanian Sumatera Barat, 2014). Kemudian campuran tanah dimasukkan ke dalam polybag $10 \mathrm{~kg}$. Letak polybag di lahan percobaan diatur sehingga antar polybag berjarak $30 \mathrm{~cm} \times 20 \mathrm{~cm}$. Bibit yang sehat dan telah memiliki dua daun selanjutnya ditanam di polybag dengan kedalam $\pm 4 \mathrm{~cm}$ dan setiap polybag ditanami satu bibit.

Pemeliharaan tanaman diawali dengan pemupukan. Pemupukan urea dilakukan dalam dua tahap, 50\% dosis diberikan pada 5 hari setelah tanam (hst) dan $50 \%$ sisanya diaplikasikan pada 15 hst. Pengairan dilakukan secara manual dengan tiga hari interval. Kriteria yang digunakan adalah kapasitas lapang tanah $(100 \%)$ dan kebutuhan air berdasarkan bobot segarnya, dimana tanaman sawi menerima $1.282,5 \mathrm{~mL}(95 \%$ bobot segar) dan tanaman pakcoy $1.215 \mathrm{~mL}(90 \%$ bobot segar). Pemeliharaan tanaman lainnya meliputi penyulaman dan penyiangan dilakukan secara manual, pengendalian hama dan penyakit secara kimiawi.

\section{Pengukuran Pertumbuhan Tanaman}

Tanaman sawi hijau dan pakcoy masing-masing dipanen pada 30 dan 27 hst saat daun terbawahnya telah menua. Panen dilakukan dengan cara mencabut tanaman dari dalam polibag, kemudian kotoran yang menempel dibersihkan. Variabel yang digunakan untuk menilai kinerja pertumbuhan tanaman meliputi (1) tinggi tanaman, diukur saat panen menggunakan meteran dari permukaan tanah sampai daun tertinggi, (2) jumlah daun yang telah membuka sempurna, (3) luas daun, diukur saat panen secara gravimetri, (4) bobot segar dan kering akar, diperoleh dengan menimbang seluruh akar yang telah bersih untuk berat segar dan menimbang akar yang telah dikeringkan di dalam oven pada suhu $60{ }^{0} \mathrm{C}$ selama tiga hari sampai bobotnya konstan untuk berat kering, (5) bobot segar daun, diperoleh dengan cara menimbang daun (tanpa tangkainya) dengan menggunakan timbangan analitik, (6) bobot segar dan kering biomassa tanaman, diperoleh dengan menimbang bobot seluruh tanaman (tanpa akar) untuk bobot segar dan menimbang biomassa segar yang telah dikeringkan di dalam oven pada suhu $60^{\circ} \mathrm{C}$ selama tiga hari sampai bobotnya konstan untuk bobot kering biomassa, dan (7) kandungan nitrat $\left(\mathrm{NO}_{3}{ }^{-}\right)$daun, ditentukan dengan analisis kolorimetri melalui titrasi asam salisilat dengan metode Cataldo et al. (1974).

\section{Analisis Statistik}

Data dianalisa secara statistik dengan SPSS 21.0 software (SPSS Inc.). Analisis ragam (ANAVA) pada tingkat kepercayaan 5\% digunakan untuk mengetahui pengaruh perlakuan, dan uji BNT digunakan untuk menentukan perbedaan antar perlakuan.

\section{HASIL DAN PEMBAHASAN}

\section{Karakteristik Tanah dan Kompos Azolla}

Analisis tanah awal menunjukkan bahwa tanah yang digunakan memiliki tingkat kesuburan yang rendah dicirikan dengan rendahnya nilai $\mathrm{pH}$ tanah, kandungan N (\%), P (ppm), dan \%C. Sedangkan kompos Azolla yang digunakan memiliki kandungan unsur $\mathrm{N}$ (\%), P (ppm), dan \%C yang tinggi. Karakteristik tanah dan kompos Azolla seperti terlihat pada Tabel 1.

Tabel 1. Karakteristik tanah pada awal penelitian dan kandungan nutrisi kompos Azolla

\begin{tabular}{l|c|c|c|c}
\hline \multicolumn{1}{c}{ Karakteristik } & \multicolumn{2}{c|}{ Tanah } & \multicolumn{2}{c}{ Kompos Azolla } \\
\cline { 2 - 6 } \multicolumn{1}{c|}{ yang diukur } & Nilai & Keterangan* & Nilai & Keterangan* \\
\hline $\mathrm{pH}\left(\mathrm{H}_{2} \mathrm{O}\right)$ & 4,08 & Masam & - & - \\
\hline $\mathrm{N}(\%)$ & 0,21 & Rendah & 3,08 & Tinggi \\
\hline $\mathrm{P}(\mathrm{ppm})$ & 2,05 & Rendah & 0,33 & Tinggi \\
\hline $\mathrm{C}(\%)$ & 1,48 & Rendah & 0,57 & Tinggi \\
\hline $\mathrm{K}(\mathrm{me} / 100)$ & 0,29 & & - & - \\
\hline Al-dd $(\mathrm{me} / 100)$ & 1,21 & & 7,31 & Rendah \\
\hline $\mathrm{KTK}(\mathrm{me} / 100)$ & 13,08 & & & \\
\hline $\mathrm{BV}\left(\mathrm{g} / \mathrm{cm}^{3}\right)$ & 1,09 & & & \\
\hline
\end{tabular}

Keterangan : Balai Penelitian Tanah (2009) 


\section{Karakteristik Pertumbuhan Tanaman}

Hasil analisis menunjukkan bahwa pertumbuhan tanaman sawi hijau tertinggi dihasilkan oleh perlakuan $\mathrm{IF}_{100}$ meskipun berbeda tidak nyata $(\mathrm{p}>0,05)$ dengan yang dihasilkan oleh perlakuan $\mathrm{IF}_{75}+\mathrm{AC}_{25}$ dan terendah oleh $\mathrm{AC}_{100}$ (Tabel 2). Pertumbuhan tanaman yang dihasilkan oleh perlakuan $\mathrm{IF}_{100}$ lebih tinggi daripada yang dihasilkan oleh perlakuan $\mathrm{IF}_{50}+\mathrm{AC}_{50}, \mathrm{IF}_{25}+\mathrm{AC}_{75}$, dan $\mathrm{AC}_{100}$. Perlakuan $\mathrm{CF}_{75}+\mathrm{AC}_{25}$ menghasilkan pertumbuhan tanaman lebih tinggi daripada $\mathrm{AC}_{100}$ (Tabel 2). Tinggi tanaman, jumlah daun, luas daun, dan bobot segar akar untuk perlakuan $\mathrm{IF}_{75}+\mathrm{AC}_{25}$ secara berturut-turut lebih tinggi $40 \%, 31 \%, 29 \%$, dan $20 \%$ daripada perlakuan $\mathrm{AC}_{100}$. Pada pakcoy, pertumbuhan tanaman (terutama tinggi tanaman) tertinggi dihasilkan oleh perlakuan $\mathrm{IF}_{75}+\mathrm{AC}_{25}$ dan berbeda nyata dengan $\mathrm{IF}_{100}, \mathrm{IF}_{50}+\mathrm{AC}_{50}, \mathrm{IF}_{25}+\mathrm{AC}_{75}$, dan $\mathrm{AC}_{100}$. Sementara itu, tinggi tanaman pada perlakuan $\mathrm{IF}_{100}, \mathrm{IF}_{50}+\mathrm{AC}_{50}, \mathrm{IF}_{25}+\mathrm{AC}_{75}$, dan $\mathrm{AC}_{100}$ saling berbeda tidak nyata $((\mathrm{p}>0,05)$ (Tabel 3$)$. Tinggi tanaman yang dihasilkan oleh perlakuan $\mathrm{IF}_{75}$ $+\mathrm{AC}_{25}$ secara berturut-turut lebih tinggi $10,08 \%$, $9,66 \%, 14,97 \%$, dan $11,22 \%$ daripada perlakuan $\mathrm{IF}_{100}, \mathrm{IF}_{50}+\mathrm{AC}_{50}, \mathrm{IF}_{25}+\mathrm{AC}_{75}$, dan $\mathrm{AC}_{100}$. Peneliti lain juga melaporkan hasil yang serupa dengan penelitian ini, yaitu pemberian pupuk perpaduan antara urea dan kompos yang tepat meningkatkan pertumbuhan tanaman bayam (Amir et al., 2012), tanaman selada (Hernandez et al., 2016), dan tanaman jagung (Zhang et al., 2016; Geng et al., 2019).

Tabel 2. Pengaruh pemberian pupuk urea yang dipadukan dengan kompos Azolla terhadap pertumbuhan sawi hijau

\begin{tabular}{|c|c|c|c|c|c|}
\hline \multirow{2}{*}{ Perlakuan } & TT & \multirow{2}{*}{ JD (helai) } & LD & BSA & BKA \\
\hline & $(\mathrm{cm})$ & & $(\mathrm{cm})$ & $(\mathrm{g})$ & $(\mathrm{g})$ \\
\hline $100 \%$ urea (kontrol) & $38,57 \mathrm{a}$ & $9,67 \mathrm{a}$ & $36,73 \mathrm{a}$ & $2,84 \mathrm{a}$ & 1,74 \\
\hline $75 \%$ urea $+25 \%$ kompos Azolla & $35,20 \mathrm{ab}$ & $8,44 \mathrm{ab}$ & $33,49 \mathrm{ab}$ & $2,83 \mathrm{a}$ & 1,61 \\
\hline $50 \%$ urea $+50 \%$ kompos Azolla & $32,94 \mathrm{bc}$ & $7,89 \mathrm{bc}$ & $30,30 \mathrm{bc}$ & $2,59 \mathrm{ab}$ & 1,62 \\
\hline $25 \%$ urea $+75 \%$ kompos Azolla & $30,56 \mathrm{c}$ & $7,89 \mathrm{bc}$ & $29,14 \mathrm{bc}$ & $2,80 \mathrm{a}$ & 1,62 \\
\hline $100 \%$ kompos Azolla & $25,17 \mathrm{~d}$ & $6,44 \mathrm{c}$ & $25,90 \mathrm{c}$ & $2,36 \mathrm{~b}$ & 1,48 \\
\hline
\end{tabular}

Tabel 3. Pengaruh pemberian pupuk urea yang dipadukan dengan kompos Azolla terhadap pertumbuhan pakcoy

\begin{tabular}{|c|c|c|c|c|c|}
\hline \multirow{2}{*}{ Perlakuan } & TT & \multirow{2}{*}{ JD (helai) } & LD & BSA & BKA \\
\hline & $(\mathrm{cm})$ & & $(\mathrm{cm})$ & (g) & $(\mathrm{g})$ \\
\hline $100 \%$ urea (kontrol) & $23,51 \mathrm{~b}$ & 15,66 & 1381,11 & 8,58 & 1,37 \\
\hline $75 \%$ urea $+25 \%$ kompos Azolla & $25,88 \mathrm{a}$ & 14,15 & 1167,93 & 6,97 & 1,22 \\
\hline $50 \%$ urea $+50 \%$ kompos Azolla & $23,26 \mathrm{~b}$ & 14,22 & 1198,72 & 8,37 & 1,39 \\
\hline $25 \%$ urea $+75 \%$ kompos Azolla & $22,51 \mathrm{~b}$ & 15,78 & 1474,44 & 8,9 & 1,41 \\
\hline $100 \%$ kompos Azolla & $23,27 \mathrm{~b}$ & 15,33 & 1301,58 & 7,53 & 1,33 \\
\hline
\end{tabular}

Keterangan : Angka-angka pada kolom yang sama, diikuti dengan huruf yang sama berbeda tidak nyata pada BNT 5\%. TT:Tinggi Tanaman, JD : Jumlah Daun, LD : Luas Daun, BSA:Bobot Segar Akar, BKA : Bobot Kering Akar.

\section{Hasil Biomassa Tanaman}

Untuk biomassa tanaman yang dihasilkan, hasil analisis menunjukkan bahwa perlakuan $\mathrm{IF}_{100}$ menghasil- kan bobot segar daun (BSD), bobot segar (BST) dan bobot kering tanaman (BKT) tertinggi meskipun berbeda tidak nyata $(\mathrm{p}>0,05)$ dengan perlakuan $\mathrm{IF}_{75}$ $+\mathrm{AC}_{25}$ dan perlakuan $\mathrm{AC}_{100}$ terendah baik untuk sawi hijau maupun pakcoy (Tabel 4 dan 5). Perlakuan $\mathrm{IF}_{100}$ ini menghasilkan $\mathrm{BSD}$, BST dan BKT lebih tinggi daripada perlakuan $\mathrm{IF}_{50}+\mathrm{AC}_{50}, \mathrm{IF}_{25}+$ $\mathrm{AC}_{75}$, dan $\mathrm{AC}_{100}(\mathrm{p}<0.05)$ untuk sawi hijau maupun pakcoy. Sementara itu, BSD, BST dan BKT pada perlakuan $\mathrm{IF}_{75}+\mathrm{AC}_{25}$ berbeda tidak nyata dengan $\mathrm{IF}_{50}$ $+\mathrm{AC}_{50}$ dan $\mathrm{IF}_{25}+\mathrm{AC}_{75}$. Untuk sawi hijau, perlakuan $\mathrm{IF}_{100}$ menghasilkan BSD, BST dan BKT lebih tinggi secara berturut-turut $27,72 \%, 25,76 \%$, dan $14,70 \%$ daripada $\mathrm{IF}_{50}+\mathrm{AC}_{50}, 31,52 \%, 39,30 \%$, dan $21,67 \%$ daripada $\mathrm{IF}_{25}+\mathrm{AC}_{75}$, dan 48,42\%, 51,69\%, dan $28,00 \%$ daripada $\mathrm{AC}_{100}$. Untuk pakcoy, perlakuan $\mathrm{IF}_{100}$ menghasilkan BSD, BST dan BKT lebih tinggi secara berturut-turut $30,65 \%, 34,82 \%$, dan $24.77 \%$ daripada $\mathrm{IF}_{50}+\mathrm{AC}_{50}, 38,75 \%, 38,39 \%$, dan $36,97 \%$ daripada $\mathrm{IF}_{25}+\mathrm{AC}_{75}$, dan 46,29\%, 44,23\%, dan $50,55 \%$ daripada $\mathrm{AC}_{100}$. Peneliti lain juga melaporkan hasil yang serupa dengan penelitian ini, yaitu pemberian pupuk perpaduan antara urea dan kompos yang tepat meningkatkan bobot kering tanaman bayam (Amir et al., 2012), tanaman selada (Hernandez et al., 2016), dan tanaman jagung (Wen et al., 2016; Zhang et al., 2016; Martineza et al., 2017; Wang et al., 2017; Geng et al., 2019). Peningkatan pertumbuhan awal kelapa sawit karena pemberian kombinasi pupuk anorganik dan organik juga dilaporkan oleh Agung et al. (2019).

Tabel 4. Pengaruh pemberian pupuk urea yang dipadukan dengan kompos Azolla terhadap hasil biomassa sawi hijau

\begin{tabular}{|l|c|c|c|c|}
\hline \multirow{2}{*}{ Perlakuan } & BSD & BST & BKT & KND \\
\cline { 2 - 5 } & $(\mathrm{g})$ & $(\mathrm{g})$ & $(\mathrm{g})$ & $(\mathrm{mg} / \mathrm{kg})$ \\
\hline $100 \%$ urea (kontrol) & $7,97 \mathrm{a}$ & $10,74 \mathrm{a}$ & $3,20 \mathrm{a}$ & 2760 \\
\hline $75 \%$ urea + 25\% kompos Azolla & $6,97 \mathrm{ab}$ & $9,35 \mathrm{ab}$ & $2,98 \mathrm{ab}$ & 1760 \\
\hline $50 \%$ urea + 50\% kompos Azolla & $6,24 \mathrm{bc}$ & $8,54 \mathrm{bc}$ & $2,79 \mathrm{bc}$ & 1440 \\
\hline $25 \%$ urea + 75\% kompos Azolla & $6,06 \mathrm{bc}$ & $7,71 \mathrm{bc}$ & $2,63 \mathrm{bc}$ & 1170 \\
\hline $100 \%$ kompos Azolla & $5,37 \mathrm{c}$ & $7,08 \mathrm{c}$ & $2,50 \mathrm{c}$ & 1080 \\
\hline
\end{tabular}

Keterangan : Angka-angka pada kolom yang sama, diikuti dengan huruf yang sama berbeda tidak nyata pada BNT 5\%. BSD:Bobot Segar Daun, BST : Bobot Segar Tanaman, BKT : Bobot Kering Tanaman, KND:Kandungan Nitrat Daun

Temuan ini menunjukkan bahwa pemberian pupuk $\mathrm{N}$ anorganik yang dipadukan dengan kompos Azolla $\left(\mathrm{IF}_{75}+\mathrm{AC}_{25}\right)$ merupakan perlakuan yang terbaik untuk meningkatkan pertumbuhan tanaman sawi hijau dan pakcoy. Hal ini mengindikasikan bahwa substitusi pupuk $\mathrm{N}$ anorganik dengan kompos Azolla yang tepat mendorong pertumbuhan tanaman yang optimal karena ketersediaan unsur hara (terutama N) di dalam tanah dari perlakuan tersebut dalam kondisi seimbang sehingga dapat mengimbangi kebutuhan unsur hara yang diserap oleh tanaman selama pertumbuhannya (Kramer et 
al., 2002). Diacono \& Montemurro (2010) menambahkan bahwa kompos menyediakan unsur hara $\mathrm{C}$ dan $\mathrm{N}$ organik yang dapat meningkatkan kesuburan tanah dan mendorong aktivitas enzim dan mikroba tanah untuk mendekomposisi dan mendaur ulang unsur hara di dalam tanah (Ros et al., 2006). Selain efek positif dari pemberian kompos terhadap struktur tanah yang mengarah pada perkembangan akar yang lebih baik bagi tanaman sehingga menyebabkan serapan hara yang lebih banyak, kompos tidak hanya melepaskan hara secara perlahan tetapi juga mencegah hilangnya pupuk anorganik melalui denitrifikasi, penguapan dan pencucian dengan mengikat nutrisi dan kemudian melepaskannya seiring dengan pertumbuhan tanaman (Kramer et al., 2002). Karena itu, penggunaan pupuk anorganik dan organik secara terpadu dapat meningkatkan efisiensi penggunaan pupuk anorganik melalui pengurangan terhadap dosis yang diberikan dengan tetap meningkatkan produktivitas tanaman dan menjaga kesehatan dan kesuburan tanah.

Pemberian pupuk urea $100 \%\left(\mathrm{IF}_{100}\right)$ menjadi penyebab utama terhadap ketidakseimbangan unsur hara di dalam tanah sehingga menyebabkan kehilangan $\mathrm{N}$ yang tinggi, terutama $\mathrm{N}$ dari pupuk anorganik tersebut, dan pemulihan $\mathrm{N}$ yang rendah (30\%) (Krupnik et al., 2004). Hal ini menyebabkan perlakuan ini berbeda tidak nyata dengan $\mathrm{IF}_{75}+\mathrm{AC}_{25}$ meskipun berbeda nyata dengan $\mathrm{IF}_{50}+\mathrm{AC}_{50}$ dan $\mathrm{IF}_{25}+\mathrm{AC}_{75}$, dan $\mathrm{AC}_{100}$.

Perlakuan $\mathrm{IF}_{50}+\mathrm{AC}_{50}$ dan $\mathrm{IF}_{25}+\mathrm{AC}_{75}$ bukan perlakuan yang baik untuk meningkatkan pertumbuhan dan hasil biomassa tanaman sawi hijau dan pakcoy. Hal ini mungkin disebabkan oleh berkurangnya jumlah pupuk $\mathrm{N}$ anorganik yang diberikan pada kedua perlakuan ini yang mengakibatkan kurangnya nutrisi (terutama N) yang tersedia. Nutrisi pupuk anorganik diketahui diambil oleh tanaman segera setelah aplikasi (Ahmad et al., 2008), sedangkan nutrisi yang berasal dari kompos (termasuk kompos Azolla) pertama-tama harus termineralisasi dan kemudian diubah menjadi bentuk yang dapat diserap oleh tanaman. Nutrisi yang dilepaskan dari pupuk organik secara perlahan tidak dapat dideteksi dalam jangka pendek (Pan et al., 2009).

Tabel 5. Pengaruh pemberian pupuk urea yang dipadukan dengan kompos Azolla terhadap hasil biomassa pakcoy

\begin{tabular}{|l|c|c|c|c|}
\hline \multicolumn{1}{|c}{ Perlakuan } & BSD & BST & BKT & $\begin{array}{c}\text { KND } \\
(\mathrm{mg} / \mathrm{kg})\end{array}$ \\
\hline & $(\mathrm{g})$ & $(\mathrm{g})$ & $(\mathrm{g})$ & 2820 \\
\hline $100 \%$ urea (kontrol) & $73,41 \mathrm{a}$ & $167,10 \mathrm{a}$ & $10,93 \mathrm{a}$ & 2820 \\
\hline $75 \%$ urea + $25 \%$ kompos Azolla & $64,44 \mathrm{ab}$ & $147,34 \mathrm{ab}$ & $9,58 \mathrm{ab}$ & 2590 \\
\hline $50 \%$ urea + 50\% kompos Azolla & $56,19 \mathrm{bc}$ & $123,94 \mathrm{bc}$ & $8,76 \mathrm{bc}$ & 2560 \\
\hline $25 \%$ urea + 75\% kompos Azolla & $52,91 \mathrm{c}$ & $120,75 \mathrm{c}$ & $7,98 \mathrm{bc}$ & 2490 \\
\hline $100 \%$ kompos azolla & $50,18 \mathrm{c}$ & $115,86 \mathrm{c}$ & $7,26 \mathrm{c}$ & 2310 \\
\hline $\begin{array}{l}\text { Keterangan : Angka-angka pada kolom yang sama, diikuti dengan huruf yang sama } \\
\text { berbeda tidak nyata pada BNT 5\%. BSD:Bobot Segar Daun, BST : Bobot Segar } \\
\text { Tanaman, BKT : Bobot Kering Tanaman, KND:Kandungan Nitrat Daun }\end{array}$ \\
\hline
\end{tabular}

Pemberian $100 \%$ kompos Azolla $\left(\mathrm{AC}_{100}\right)$ menghasilkan pertumbuhan dan hasil biomassa tanaman
Konsentrasi nitrat pada daun sawi hijau dan pakcoy tertinggi pada perlakuan $\mathrm{IF}_{100}$ diikuti secara berturut-turut $\mathrm{IF}_{75}+\mathrm{AC}_{25}, \mathrm{IF}_{50}+\mathrm{AC}_{50}, \mathrm{IF}_{25}+\mathrm{AC}_{75}$, dan terendah pada $\mathrm{AC}_{100}$ (Tabel 4 dan 5). Pada kedua tanaman tersebut, perbedaan kandungan nitrat yang tinggi teramati antara $100 \%$ pemupukan anorganik $\left(\mathrm{IF}_{100}\right)$ dan organik $\left(\mathrm{AC}_{100}\right)$. Daun sawi hijau dan pakcoy yang ditanam secara organik (diperlakukan dengan 100\% kompos Azolla) mengandung nitrat dengan konsentrasi lebih rendah (156\% pada sawi dan $22 \%$ pada pakcoy) daripada ditanam secara kimiawi (pemberian $100 \%$ pupuk $\mathrm{N}$ anorganik atau $\mathrm{IF}_{100}$ ). Hal ini terjadi karena mineralisasi kompos berlangsung lambat sehingga menyebabkan penyerapan $\mathrm{N}$ oleh tanaman berlangsung secara lebih bertahap. Lambatnya penyerapan $\mathrm{N}$ ini memberikan waktu yang lebih lama untuk berlangsungnya proses metabolisme dan untuk produksi senyawa organik, sehingga ujungnya mengurangi akumulasi nitrat di dalam tanaman (Pavlou et al., 2007). Sedangkan menurut Tong et al. (1997), hal ini disebabkan kandungan $\mathrm{NO}_{3}-\mathrm{N}$ di dalam tanah diminimalisir dengan aplikasi pupuk kandang dosis tinggi sehingga $\mathrm{NO}_{3}-\mathrm{N}$ yang diserap oleh akar tanaman yang kemudian diakumulasikan di daun juga rendah. Hasil penelitian ini mendukung penelitian Ogzen et al. (2014) dan Hernadez et al. (2016) yang melaporkan bahwa pemberian pupuk organik mengurangi konsentrasi nitrat pada selada $38-50 \%$ dibandingkan dengan pemberian pupuk anorganik.

Kadar nitrat pada daun sawi hijau dan pakcoy dari hasil penelitian ini masih berada dibawah batas kadar nitrat yang ditetapkan oleh peraturan UE (Commision Regulation No 1258/2011). Sebagai pembanding, batas kadar nitrat daun selada yang dibudidayakan di rumah kaca yang aman dikonsumsi sebesar $4000 \mathrm{mg} / \mathrm{kg}$, sedangkan batas maksimal nitrat di sayuran di China yang aman dikonsumsi ditetapkan sebanyak $3100 \mathrm{mg} / \mathrm{kg}$ (Zhou et al., 2000).

\section{KESIMPULAN}

Pemberian kombinasi pupuk $\mathrm{N}$ anorganik dan kompos Azolla secara berimbang pada dosis 31,0 mg N/ $\mathrm{kg}$ tanah dan kompos Azolla $1000 \mathrm{mg} / \mathrm{kg}$ tanah menghasilkan tinggi tanaman, berat segar daun, bobot segar tanaman dan bobot kering tanaman sawi hijau dan pakcoy sama tingginya dengan pemberian pupuk $\mathrm{N}$ anorganik secara tunggal dengan dosis $42,0 \mathrm{mg} \mathrm{N} / \mathrm{kg}$ tanah. Pemberian kombinasi pupuk $\mathrm{N}$ anorganik dan kompos Azolla secara berimbang pada dosis ini menghasilkan daun dengan kandungan nitrat lebih rendah dari batas maksimal nitrat yang aman dikonsumsi yang ditetapkan sebanyak $3100 \mathrm{mg} / \mathrm{kg}$. Penggunaan kompos Azolla untuk budidaya sawi hijau dan pakcoy yang dikombinasikan dengan pupuk $\mathrm{N}$ anorganik mengurangi kebutuhan pupuk $\mathrm{N}$ anorganik tersebut hingga $25 \%$ dari dosis pupuk $\mathrm{N}$ anorganik anjuran. 


\section{DAFTAR PUSTAKA}

Agung, A. K., Adiprasetyo, T. \& Hermansyah, H. (2019). Penggunaan kompos tandan kosong kelapa sawit sebagai subtitusi pupuk npk dalam pembibitan awal kelapa sawit. Jurnal Ilmu-Ilmu Pertanian Indonesia, 21(2), 75-81. DOI: https://doi.org/ 10.31186/jipi.21.2.75-81.

Ahmad, R., Naveed, M., Aslam, M., Zahir, Z.A. \& Arshad, M. (2008). Economizing the use of nitrogen fertilizer in wheat production through enriched compost. Renewable Agriculture and Food Systems, 23, 243-249.

Amir, L., Sari, A.P., Hiola, S.F. \& Jumadi, O. (2012). The availability of nitrogen in soil and growth of spinach. Sainsmat. J., 1, 167-180. (in Indonesian).

Balai Penelitian Tanah. 2009. Analisis Kimia Tanah, Tanaman, Air dan Pupuk. Balai Penelitian Tanah, Bogor.

Balai Pengkajian Teknologi Pertanian Sumatera Barat. (2014). Budidaya Tanaman Sayuran. Balai Pengkajian Teknologi Pertanian Sumatera Barat,Padang.

Brady, N.C. \& Weil, R.R. (2008). Soil Colloids: Seat of Soil Chemical and Physical Acidity. In The Nature and Properties of Soils (pp. 311-358); Brady, N.C., Weil, R.R., Eds. Pearson Education Inc., Upper Saddle River, NJ.

Cataldo, D. A., Schrader, L. E. \& Youngs, V. L. (1974). Analysis by digestion and colorimetric assay of total nitrogen in plant tissues high in nitrate. Crop Science, 14(6), 854-856.

Diacono, M. \& Montemurro, F. (2010). Long-term effects of organic amendments on soil fertility. A review. Agron. Sustain. Dev., 30, 401-422. DOI: https:// doi.org/10.1051/agro/2009040.

Donner, S.D., \& Kucharik, J.A. (2003). Evaluating the impacts of land management and climate variability on crop production and nitrate export across the Upper Mississippi Basin. Global Biogeochem. Cycle., 17.

FAO. (2006). World reference base for soil resources 2006. World Soil Resources Reports 103. FA.

Garcia-Ruíz, R., Ochoa, M.V., Hinojosa, M.B. \& Gómez-Muñoz, B. (2012). Improved soil quality after 16 year of olive mil pomace application in olive oil groves. Agron. Sustain. Dev., 32, 803-810.

Geng, Y., Cao, G., Wang, L. \& Wang, S. (2019). Effects of equal chemical fertilizer substitutions with organic manure on yield, dry matter, and nitrogen uptake of spring maize and soil nitrogen distribution. PLoS ONE 14(7): e0219512. DOI: $\quad$ https://doi.org/10.1371/journal.pone. 0219512 .
Hernández, T., Chocano, C., Moreno, J. L., \& García, C. (2016). Use of compost as an alternative to conventional inorganic fertilizers in intensive lettuce (Lactuca sativa L.) crops-Effects on soil and plant. Soil and Tillage Research, 160, 14-22.

Hirzel, J., \& Salazar, F. (2011). Uso de enmiendas orgánicas como fuente de fertilización en Cultivos (Use of organic amendments as source of fertilization in crops). Fertilización de cultivos en Chile (Crop Fertilization in Chile) (pp. 434), Hirzel, J. (Ed.). Chillán, Chile : Colección Libros INIA N28.

International Fertilizer Association-IFA.(2018). Fertilizer outlook 2018-2022 - Production \& International Trade and Agriculture Services. In: $86^{\text {th }}$ IFA Annual Conference; June 18-20, 2018; Berlin, Germany. Berlin: IFA; 2018. Available from: https://www.fertilizer.org/images/Library Downloads/2018_IFA_Annual_Conference_ Berlin PIT AG_Fertilizer_Outlook.pdf.

Jumadi, O., Hiola, S. F., Hala, Y., Norton, J. \& Inubushi, K. (2014). Influence of Azolla (Azolla microphylla Kaulf.) compost on biogenic gas production, inorganic nitrogen and growth of upland kangkong (Ipomoea aquatica Forsk.) in a silt loam soil. Soil Science and Plant Nutrition, 60(5), 722-730.

Kramer, A.W., Doane, T.A., Horwath, W.R., \& Van, K.C. (2002). Combining fertilizer and organic inputs to synchronize $\mathrm{N}$ supply in alternative cropping systems in California. Agriculture, Ecosystems and Environment, 91, 233243.

Krupnik, T.J., Six, J., Ladha, J.K., Paine, M.J., Kessel, C.V. (2004). An assessment of fertilizer nitrogen recovery efficiency by grain crops.A.R.Mosier (Ed.), Agriculture and the Nitrogen Cycle: Assessing the Impacts of Fertilizer Use on Food Production and the Environment, Scientific Committee on Problems of the Environment, Paris, France.

Kumar-Premi, O.P. \& Thomas, L.(2015).Rapeseed Mustard cultivation in India - an overview (pp. 303-321), National Research Centre on RapeseedMustard, Bharatpur (Rajasthan).

Liu, C. W., Sung, Y., Chen, B. C. \& Lai, H. Y. (2014). Effects of nitrogen fertilizers on the growth and nitrate content of lettuce (Lactuca sativa L.). International Journal of Environmental Research and Public Health, 11(4), 4427-4440.

Martíneza, E., Domingo, F., Roselló, A., Serra, J., Boixadera, J. \& Lloveras J. (2017). The effects of dairy cattle manure and mineral $\mathrm{N}$ fertilizer on irrigated maize and soil $\mathrm{N}$ and organic. Europ. J. Agronomy, 83, 78-85. DOI: https://doi. org/10.1016/j.eja.2016.10.002. 
Otto, R., Zavaschi, E., Souza-Netto, G.J.M., Machado, B.A. \& Mira, A.B. (2017). Ammonia volatilization from nitrogen fertilizers applied to sugarcane straw. Rev. Cienc. Agron., 48, 413418. DOI: $10.5935 / 1806-6690.20170048$.

Pan, G.X., Smith, P. \& Pan, W.N. (2009). The role of soil organic matter in maintaining the productivity and yield stability of cereals in China. Agriculture, Ecosystems and Environment, 129, 344-348.

Pannala, A.S., Mani, A.R., Spencer, J.P.E., Skinner, V., Bruckdorfer, K.R., Moore, K.P. \& RiceEvans, C.A. (2003). The effect of dietary nitrate on salivary, plasma, and urinary nitrate metabolism in humans. Free Rad. Biol. Med., 34, 576-584.

Pavlou, G.C.,Ehaliotis,C.D.\&Kavvadias,V.A. (2007). Effect of organic and inorganic fertilizers applied during successive crop seasons on growth and nitrate accumulation in lettuce. Sci. Hortic., 111, 319-325.

Prasad, S. \& Chetty, A.A. (2008). Nitrate-N determination in leafy vegetables: Study of the effects of cooking and freezing. Food Chem., 106, 772 -780 .

Ros, M., Pascual, J.A., Garcia, C., Hernandez, M.T. \& Insam, H. (2006). Hydrolase activities, microbial biomass and bacterial community in a soil after long-term amendment with different composts. Soil Biol. Biochem., 38, 3443-3452.

Santamaria, P. (2006). Nitrate in vegetables: toxicity, content, intake and EC regulation. Journal of the Science of Food and Agriculture, 86(1), 10-17.

Sharifi, M., Zebarth, B.J., Burton, D.L., Rodd, V. \& Grant, C.A. (2011). Long-term effects of semisolid beef manure application to forage grass on soil mineralizable nitrogen. Soil Sci. Soc. Amer. J., 75, 649658. DOI: https://doi.org/10.2136/sssaj 2010. 0089.

Silva, A.G.B., Sequeira, C.H., Sermarini, R.A., \& Otto, R. (2017). Urease inhibitor NBPT on ammonia volatilization and crop productivity: A meta-analysis. Agron. J., 109, 1-13. DOI: https://doi.org/10.2134/agronj2016.04.0200.

Stafanato, J.B., Goulart, R.S., Zonta, E., Lima, E., Mazur, N., Pereira, C.G. \& Souza, H.N. (2013). Volatilização de amônia oriunda de ureia pastilhada com micronutrientes em ambiente controlado. Rev Bras Cienc Solo, 37, 726-32. DOI: https://doi.org/10.1590/S010006832013000300019 .
Sunderlage, B. \& Cook, R.L. (2018). Soil property and fertilizer additive effects on ammonia volatilization from urea. Soil Sci. Soc. Am. J., 82, 253-259. DOI: https://doi.org/10.2136/sssaj 2017.05.0151.

Tamme, T., Reinik, M. \& Roasto, M. (2009). Nitrates and Nitrites in Vegetables: Occurrence and Health Risks. In Bioactive Foods Promoting Health (pp. 307-321). Fruits and Vegetables; Watson, R.R., Preedy, V.R, Eds. Academic Press, UT.

Tasca, F.A., Ernani, P.R., Rogeri, D.A., Gatiboni, L.C. \& Cassol, P.C. (2011). Volatilização de amônia do solo após a aplicação de ureia convencional ou com inibidor de urease. Rev Bras Cienc Solo, 35, 493-502.

Tong, Y.N., Emteryd, O., Lu, D.Q. \& Grip, H. (1997). Effect of organic manure and chemical fertilizer on nitrogen uptake and nitrate leaching in a Eumorthic anthrosols profile. Nutr Cycl Agroecosys., 48, 225-229.

Wang, Z.H., Zong, Z.Q., Li, S.X. \& Chen, B.M. (2002). Nitrate accumulation in vegetables and its residual in vegetable fields. Environ. Sci., 23, 79-83.

Wen, Z.H., Shen, J.B., Martin, B., Li, H.G., Zhao, B.Q. \& Yuan, H.M. (2016). Combined Applications of Nitrogen and Phosphorus Fertilizers with Manure Increase Maize Yield and Nutrient Uptake via Stimulating Root Growth in a Long-Term Experiment. Pedosphere, 26(1), 62-73. DOI: https://doi.org/10.1016/S10020160(15)60023-6.

Ximenes, M.I.N. Rath, S. \& Reyes, F.G.R. (2000). Polargraphic determination of nitrate in vegetables. Talanta, 51, 49-56.

Zebarth, B.J., Drury, C.F., Tremblay, N. \& Cambouris, A.N. (2009). Opportunities for improved fertilizer nitrogen management in production of arable crops in eastern Canada: A review. Can. J. Soil Sci., 89, 113-132.

Zhang, Y., Li, C., Wang, Y., Hu, Y., Christie, P., Zhang, J. \& Li, X. (2016). Maize yield and soil fertility with combined use of compost and inorganic fertilizers on a calcareous soil on the North China Plain. Soil and Tillage Research, 155, 85-94.DOI:https://doi.org/10.1016/j.still.2015. 08.006.

Zhou, Z.Y., Wang, M.J., \& Wang, J.S. (2000). Nitrate and nitrite contamination in vegetables in China. Food Rev. Int., 16, 61-76. 